Олександр Петрачков, кандидат педагогічних наук, Національний університет оборони України імені Івана Черняховського

ORCID ID 0000-0002-6684-1641

Віталій Поливанюк,

Національний університет оборони України імені Івана Черняховського

ORCID ID 0000-0002-4737-1218

DOI: $10.33099 / 2617-1775 / 2021-01 / 234-245$

\title{
ВИЗНАЧЕННЯ ПЕДАГОГІЧНИХ УМОВ ФОРМУВАННЯ ПРОФЕСІЙНОЇ КОМПЕТЕНТНОСТІ МАЙБУТНІХ ФАХІВЦІВ 3 ФІЗИЧНОЇ КУЛЬТУРИ І СПОРТУ ЗБРОЙНИХ СИЛ УКРАЇНИ
}

Проаналізовано теоретичні підходи до визначення категорії «педагогічні умови». Досліджено сучасні точки зору щуодо визначення організачійно-педагогічних умов формування професійної компетентності майбутніх військових фахівців з фізичної культури і спорту Збройних Сил України.

Наведено важливе для изього дослідження трактування терміну «умова» 3 психологічної точки зору як сукупності явищ зовнішнього та внутрішнього середовища, які можуть здійснювати вплив на розвиток конкретного явища, що опосередковується активністю особи чи певної групи осіб. Розглянуто в якості значущих умов професійного становлення особистості мотиви, спрямованість особистості, її нахили, інтереси, загальні та особливі здібності, обставини виховання та навчання, організаиіі професійного та освітнього середовища, доступ до культурних иінностей, стан сочіального оточення тощзо.

Висвітлено позищї вчених та дослідників про те, щчо формування професійної компетентності є діалектичним процесом, який зумовлений зовнішніми та внутрішніми стимулами, щьо дозволяе виокремити організаційно-педагогічні умови стимулювання професійної компетентності майбутнього військового фахівия. Визначено зовнішні та внутрішні аспекти формування професійної компетентності. У зовнішньому аспекті формування професійної компетентності стимулюється цілеспрямованим включенням курсантів у різноманітні види діяльності. Саме від того, наскільки тісною і плідною $\epsilon$ взаємодія середовища вищого військового навчального закладу і особистісних можливостей курсанта, настільки успішнішим виявлясться формування професійної компетентності майбутніх військових фахівців. $У$ внутрішньому аспекті формування професійної компетентності розкривається через професійне усвідомлення особистості себе як майбутнього професіонала, усвідомленій здатності до проектування власного професійного иляху, критичному ставленні до своїх професійних здобутків. Майбутній фахівець внутрішньо прагне до професійного саморозвитку, тобто на рівні особистості спостерігаються певні якісні зміни у прагненні до професійного самовдосконалення, виробленні певного стилю професійної діяльності.

Ключові слова: організаційно-педагогічні умови, професійна компетентність, професійний розвиток, саморозвиток, педагогічне моделювання.

Постановка проблеми. Сучасний стан системи підготовки педагогічних кадрів $є$ закономірним результатом впливу не тільки консервативності системи вітчизняної освіти, а й конфліктів та колізій, які мають місце у сучасному суспільстві. Для освітньої системи характерна певна дисгармонія з потребами сучасного соціуму. Відповідно, наслідком цього $є$ значне поглиблення та 
загострення освітніх проблем. Тому питання щодо професійної підготовки майбутніх військових фахівців в нашій країні посідають ключове місце у сучасних педагогічних та психологічних дослідженнях. До того ж, актуальність проблеми визначення педагогічних умов формування професійної компетентності майбутніх фахівців з фізичної культури і спорту збройних сил України зумовлена євроінтеграцією України, курсом нашої держави на вступ до НАТО, сучасними подіями на сході України.

Аналіз останніх досліджень i публікацій. $\mathrm{y}$ ході дослідження проаналізовані наукові праці з проблеми визначення категорії «педагогічні умови» (Б. Гершунський [1], І. Зязюн [2], А. Смолюк [3], М. Фіцула [4] та ін.), визначення організаційно-педагогічних умов формування професійної компетентності як складової професійної діяльності майбутніх спеціалістів (Т. Вдовичин [5], О. Діденко [6], О. Онаць [7], В. Шемчук [11-14]), зокрема військових фахівців фізичної культури і спорту (Д. Погребняк [10]).

Аналіз сучасних наукових досліджень у сфері підготовки майбутніх офіцерів Збройних Сил України свідчить, що більшість наукових джерел стосується системи базової вищої освіти, в якій починається перехід до багаторівневої структури з різноманітними формами підготовки спеціалістів 3 фізичної культури і спорту. В свою чергу питання визначення педагогічних умов формування професійної компетентності майбутніх фахівців 3 фізичної культури i спорту Збройних Сил України залишаються недостатньо дослідженими.

Мета статті полягає у дослідженні теоретичних підходів до аналізу категорії «педагогічні умови» та визначенні організаційно-педагогічних умов формування професійної компетентності майбутніх військових фахівців 3 фізичної культури і спорту Збройних Сил України.

Виклад основного матеріалу. Процес формування професійної компетентності військових фахівців фізичної культури і спорту неможливий без спеціально спроектованих організаційно-педагогічних умов. Для розуміння сутності категорії «педагогічна умова» доцільно дослідити тлумачення змісту зазначеного явища. Поняття «педагогічні умови» стосується різних аспектів процесу навчання, виховання та розвитку: цілей, принципів, змісту, методів, форм, засобів тощо. Цей термін може позначати як цілісний освітній процес, так і характеризувати окремі його сторони чи елементи. Аналізуючи зміст зазначеного поняття, можливо зазначити, що незважаючи на висвітлення його багатьма дослідниками (наприклад, Ю. Бабанським, А. Вербицьким, I. Підласим, В. Сластьоніним та іншими), досліджуване поняття висвітлене недостатньо і часом у наукових дискусіях може набувати різного значення. Взагалі, під поняттям організаційно-педагогічні умови розуміються важливі фактори, які впливають на виникнення та існування того чи іншого явища.

Важливим для цього дослідження є трактування терміну «умова» 3 психологічної точки зору як сукупності явищ зовнішнього та внутрішнього середовища, які можуть здійснювати вплив на розвиток конкретного явища, що опосередковується активністю особи чи певної групи осіб. 
Саме психологи розглядають в якості значущих умов професійного становлення особистості мотиви, спрямованість особистості, ii нахили, інтереси, загальні та особливі здібності, обставини виховання та навчання, організації професійного та освітнього середовища, доступ до культурних цінностей, стан соціального оточення тощо. Суттєвим у контексті дослідження виступає поєднання як зовнішніх, так і внутрішніх впливів, і саме зовнішні впливи здатні подіяти лише через опосередковане сприйняття особою. Вагомий внесок у дослідження вказаної проблеми зробив С. Рубінштейн, який наголошував на розділенні як внутрішніх, так і зовнішніх умов. Сучасний вітчизняний дослідник А. Смолюк підтримує позицію вченого, що зовнішні умови визначають кінцевий результат не безпосередньо, а «заломлюючись» крізь дію внутрішніх умов, власну природу конкретного об'єкта чи явища. Відповідно, внутрішні умови виступають причинами, а зовнішні - обставинами $[1$, c. 75$]$.

Близькою до наведеної позиції вчених є розуміння положень дослідників про те, що формування професійної компетентності є діалектичним процесом, який зумовлений зовнішніми та внутрішніми стимулами, що дозволяє виокремити організаційно-педагогічні умови стимулювання професійної компетентності майбутнього військового фахівця. У зовнішньому аспекті формування професійної компетентності стимулюється цілеспрямованим включенням курсантів у різноманітні види діяльності. Саме від того, наскільки тісною і плідною є взаємодія середовища вищого військового навчального закладу i особистісних можливостей курсанта, настільки успішнішим виявляється формування професійної компетентності майбутніх військових фахівців. У внутрішньому аспекті формування професійної компетентності розкривається через професійне усвідомлення курсантом себе як майбутнього професіонала, усвідомленій здатності до проектування власного професійного шляху, критичному ставленні до своїх професійних здобутків. Слухач (курсант) внутрішньо прагне до професійного саморозвитку, тобто на рівні особистості спостерігаються певні якісні зміни у прагненні до професійного самовдосконалення, виробленні певного стилю професійної діяльності. Певна динаміка формування професійної компетентності усвідомлюється особистістю на різних рівнях від більшої професійної компетентності, легкості перебігу соціально-професійної адаптації під час виконання різних практичних завдань до відчуття психологічного комфорту від взаємодії з оточуючими та ін.

Педагогічні дослідження спираються на філософське тлумачення категорії «умова» як вираження ставлення предмета до навколишніх явищ, без яких він існувати не може, а також на психологічне осмислення умов як причин, чинників, засобів, під впливом яких відбувається формування професійної компетентності особистості. Дослідник Б. Гершунський вважав, що предметом методології педагогіки є: безпосередні педагогічні знання, способи їх здобуття, умови їхнього практичного впровадження і визначення предмета педагогіки [2, c. 61]. Схожої думки дотримується М. Фіцула, який стверджує, що предметом дидактики виступає не тільки процес навчання, а й умови, необхідні для його 
перебігу (зміст, засоби, методи навчання, комунікації між педагогом і учнями та ін.), а також отримані результати, їхня діагностика та оцінювання [3, с. 83].

В роботах Шемчука В.А., теоретично обгрунтовано педагогічні (організаційно-педагогічні) умови розвитку управлінського мислення майбутніх магістрів військового управління в системі післядипломної освіти: створення професійно орієнтованого навчального середовища в університеті; обгрунтування такого змісту управлінської підготовки, який враховує цілі, завдання, принципи та специфіку майбутньої управлінської діяльності, а також сприяє розвитку управлінського мислення як майбутніх суб'єктів цієї ланки управління; застосовування професійно орієнтованих методик і дидактичних технологій проведення навчальних заходів, які мають методично обгрунтовано стимулювати розвиток і вдосконалення мисленнєвих процесів із врахуванням вікових особливостей, військово-професійного й управлінського досвіду, майбутніх кар'єрних перспектив i посадових компетенцій; забезпечення самоменеджменту слухачів у навчальній діяльності; забезпечення міжпредметних зв'язків між навчальними дисциплінами [13, с. 184-185; 14, с. 386-387].

Деякі сучасні дослідники аналізують педагогічні умови як фактори (або чинники), що впливають на процес досягнення мети, при цьому вони поділяються на: зовнішні (позитивні відносини педагога і слухача; об’єктивність оцінювання процесу навчання; місце навчання, приміщення, кліматичні умови тощо) та внутрішні (індивідуальні характеристики слухачів, тобто стан здоров'я, якості характеру, досвід, уміння, навички, мотивація тощо) $[4$, c. 161$]$.

Проблемі педагогічних умов присвячене дослідження А. Литвина, в ньому під такими умовами розуміються певні особливості організації навчального процесу, які здійснюють характерний вплив на результати навчання та розвитку суб’єкта, що здобуває певну освіту, об’єктивно забезпечують можливість їх покращення шляхом використання сучасних освітніх методик навчання i виховання, інноваційних технологій, запровадження результатів передових педагогічних досліджень [5, с. 28].

Т. Вдовичин виокремлює наступні організаційно-педагогічні умови: спрямування на самореалізацію особистості завдяки створенню та підтримці інновацій в навчальному середовищі; реалізація методичних умінь та навичок у педагогів та забезпечення розвитку їх професійних компетентностей; мотивації до навчання та розвиток пізнавальної активності слухачів [6, с. 226].

3 урахуванням методологічних позицій дослідників щодо визначення поняття «педагогічні умови», доцільно підкреслити наступне. 3 одного боку, деякі дослідники, досліджуючи зазначену категорію, розуміють під нею сукупність об'єктивних можливостей вирішення освітніх завдань. 3 іншого боку, під умовами маються на увазі педагогічні вимоги, обставини, за яких компоненти освітнього процесу представлені в оптимальному взаємозв'язку; сукупність зовнішніх і внутрішніх впливів (I. Березовська [7, с. 8]). Дещо відрізняється точка зору вчених (І. Зязюн [8, с. 6] та ін.), котрі пов’язують педагогічні умови 3 формуванням системи освіти, в якій вони виступають 
одним із компонентів (факторів, обставин). Дослідники розуміють педагогічні умови як один із проявів закономірностей процесу навчання. Різносторонній аналіз існуючих трактувань категорії «педагогічні умови» дозволяє виокремити певні ознаки і положення, що $є$ ключовими в розумінні цього поняття, зокрема педагогічні умови: $\epsilon$ предметом дослідження методології педагогіки; виражають відношення освітньої системи до навколишніх явищ, без яких неможливе іiі існування; забезпечують оптимальний перебіг освітніх процесів та явищ; необхідні для досягнення визначеної педагогічної мети та вирішення поставлених завдань; поєднують суб'єктивне й об'єктивне, внутрішнє i зовнішне, сутність та явище [1, с. 76].

Узагальнюючи теоретико-методологічні підходи до проблеми дослідження, доцільно стверджувати, що організаційно-педагогічні умови формування професійної компетентності виступають складовим елементом педагогічної системи (цілісного педагогічного процесу); відображають сукупність можливостей освітнього середовища вищого військового навчального закладу (цілеспрямовано конструюються заходи впливу взаємодії освітніх суб'єктів: зміст, навчальні та виховні методи, прийоми і форми, програмно-методичне забезпечення навчально-виховного процесу) i матеріально-просторового середовища (відповідне навчальне та технічне обладнання тощо), що впливають на існування і функціонування освітньої системи. Для їхньої структури характерна наявність як внутрішніх елементів, що впливають на розвиток особистісної сфери суб'єктів освітнього процесу, так i зовнішніх обставин цього процесу. Відповідним чином обгрунтована реалізація педагогічних умов формування професійної компетентності майбутніх військових фахівців забезпечить ефективне функціонування та розвиток педагогічної системи, стимулюватиме готовність до професійного розвитку і саморозвитку.

Відповідно, в контексті цього дослідження під організаційнопедагогічними умовами варто розуміти спеціально спроектовані фактори впливу на зовнішні та внутрішні обставини професійної підготовки майбутніх начальників фізичної культури і спорту військових частин, які сприяють їхньому професійному розвитку і саморозвитку, готовності до розвитку як професійних, так і особистісних здібностей, формуванню стійких професійних компетенцій в умовах освітнього середовища вищого військового навчального закладу. 3 огляду на викладене, використання можливостей освітнього середовища передбачає реалізацію сукупності об'єктивних зовнішніх щодо курсантів предметно-просторових умов, соціальних об'єктів та освітніх факторів і впливів (зміст освіти, форми організації освітнього процесу, методи, технології тощо), необхідних для ефективного саморозвитку особистості майбутнього військового фахівця.

Д. Погребняк зазначає, що організаційно-педагогічні умови формування професійної компетентності мають бути системними та містити методологічні, теоретичні, методичні та практичні аспекти професійної підготовки майбутніх фахівців фізичної підготовки і спорту: 
- методологічний аспект - містить ключові ідеї та принципи, на основі яких здійснюється професійна підготовка;

- теоретичний аспект - передбачає: цілі, принципи, зміст та результат професійної підготовки військових фахівців;

- методичний аспект - це, в першу чергу, основні методи, технології, засоби та методика їх реалізації у навчальному процесі;

- практичний аспект - наявність сучасної навчальної матеріально-технічної бази, що відповідає сучасним вимогам оточення та специфіці діяльності начальників фізичної підготовки і спорту.

3 урахування наведених аспектів, успішний розвиток професійної компетентності майбутніх фахівців фізичної культури і спорту може відбуватися за реалізації таких організаційно-педагогічних умов:

1) педагогічне моделювання розвитку професійної компетентності майбутніх фахівців фізичної культури і спорту 3С України - це системна педагогічна умова. Моделювання передбачає можливість відобразити ключові властивості розвитку професійної компетентності. 3 іншого боку, цей напрямок $\epsilon$ наочною демонстрацією основних методологічних підходів, теоретичних та методичних основ, представленням конкретних етапів розвитку професійної компетентності зазначеної категорії офіцерів;

2) розробка сучасної комплексної методики розвитку професійної компетентності фахівців фізичної культури і спорту ЗС України: уявляє собою визначену навчальну систему, засновану на положеннях компетентнісного, системного та суб'єктно-діяльнісного підходів. Методика має містити цілі, принципи, методи, способи, прийоми та засоби на кожному з виокремлених етапів розвитку професійної компетентності. Результатом навчання за такою методикою має бути здатність фахівців фізичної культури і спорту ЗС України успішно виконувати свої функціональні обов'язки у професійній діяльності; розвиток практичних знань, умінь та навичок (включаючи і самопідготовку офіцерів);

3) забезпечення саморозвитку військових фахівців у процесі навчання: передбачає формування умов для актуалізації їх навчальної суб’єктності та суб'єктної поведінки у навчально-пізнавальній діяльності. Важливими аспектами наведеної умови є: внутрішня мотивація фахівців фізичної культури i спорту 3С України, їх прагнення досягти професіоналізму у власній діяльності; розвиток системних знань у сфері фізичного виховання і спорту; здатність розв'язувати стандартні та нестандартні завдання при виконанні своїх професійних обов'язків;

4) застосування об'єктивних критеріїв оцінки рівнів розвитку професійної компетентності майбутніх військових фахівців: в якості критерію розуміється визначальна ознака, яка характеризує конкретні якісні аспекти явища, що досліджується, та надає можливість встановити ступінь його сформованості, розвиненості, покращення та ін. Критерії знаходять своє вираження в показниках i через це існує можливість статистичного вимірювання та оцінювання певних проявів досліджуваного явища. Для визначення кількісних та якісних характеристик розвитку професійної компетентності майбутніх 
військових фахівців критерії оцінювання мають бути об'єктивними, надійними, ефективними та достовірними [4, с. 162].

Також, для визначення професійної компетентності викладено, змістовофункціональна модель формування професійних компетентностей майбутніх офіцерів - фахівців фізичної підготовки і спорту у $B B H 3$, яка містить: цільовий, організаційно-змістовий та результативно-оцінний блоки [11, с. 244-246].

Загальновідомо, що високий рівень професіоналізму позначається на успішності професійної діяльності, дає змогу особистості оптимально реалізувати власний потенціал. Реалізація педагогічних умов формування професійної компетентності майбутнього військового фахівця (начальника фізичної культури і спорту) має бути спрямованою на забезпечення виконання ним у майбутньому важливих функцій (за О. Онацем):

- управлінської - полягає у виконанні ролі керівника військовопедагогічного процесу для регулювання навчально-пізнавальної діяльності;

- менеджерської - виконання ролі інструктора, який допомагає у визначенні ресурсів виконання практичних завдань;

- контролюючої - забезпечення контролю та оцінювання досягнень;

- організаційної - організація різнопланової діяльності курсантів;

- діагностично-прогностична - виконання ролі дослідника при визначенні реального ступеня навченості та розвитку курсантів і прогнозуванні на цій основі їх освітніх траєкторій $[9$, с. 35].

За умови комбінування усіх функцій, майбутній фахівець фізичної культури і спорту ЗС України стане наставником, що сприятиме формуванню умов для налагодження повноцінної та позитивної взаємодії й співпраці 3 оточуючим колективом, а також для формування особистості професіонала 3 педагогічної точки зору. Реалізація педагогічних умов формування професійної компетентності майбутніх військових фахівців у процесі вивчення фахових дисциплін має бути спрямована на забезпечення розвитку їх ключових умінь як компетентних спеціалістів:

1) проектувати освітній процес, вдало конструювати навчальний матеріал, уміло моделювати й розв'язувати педагогічні ситуації;

2) сприймати психічний стан слухачів, визначати особливості стосунків у військовому колективі;

3) ставити коректні завдання, координувати діяльність курсантів, співпрацювати 3 ними в освітньому процесі;

4) виробляти сміливе, гнучке та позитивне мислення в пошуках оптимального вибору форм і методів навчально-виховної діяльності офіцерів;

5) оволодівати новими науково-педагогічними й науково-технічними знаннями, передовими, а також нетрадиційними і нестандартними методами ефективного регулювання стосунків з колегами, слухачами (курсантами);

6) здійснювати емоційний вплив на слухачів (курсантів);

7) проводити моніторинг навчання, виховання та розвитку офіцерів;

8) виявляти рівень ефективності та успішності власної діяльності.

Успіх діяльності майбутніх військових фахівців, в тому числі i педагогічної, визначається передусім рівнем їхньої професійної 
підготовленості. 3 накопиченням досвіду формуються оптимальні прийоми праці, приходить майстерність, яка дозволяє швидко адаптуватися до будь-якої аудиторії, виникає легкість у роботі [10, с. 33].

Висновки та перспективи подальших досліджень. Таким чином, організаційно-педагогічні умови формування професійної компетентності військових фахівців уявляють собою спеціально спроектовані фактори впливу на зовнішні та внутрішні обставини професійної підготовки майбутніх фахівців фізичної культури і спорту ЗС України, які сприяють їхньому професійному розвитку і саморозвитку, готовності до розвитку як професійних, так i особистісних здібностей, формуванню стійких професійних компетенцій в умовах освітнього середовища вищого військового навчального закладу.

Організаційно-педагогічні умови формування професійної компетентності мають бути системними та містити методологічні, теоретичні, методичні та практичні аспекти професійної підготовки фахівців фізичної культури і спорту ЗС України.

Успішний розвиток професійної компетентності фахівців фізичної культури і спорту ЗС України має відбуватися при реалізації певних організаційно-педагогічних умов: 1) педагогічне моделювання розвитку їхньої професійної компетентності; 2) формування сучасної комплексної методики розвитку досліджуваної професійної компетентності; 3) забезпечення саморозвитку начальників фізичної підготовки і спорту у навчальному процесі; 4) застосування об'єктивних критеріїв оцінювання рівнів розвитку професійної компетентності майбутніх військових фахівців.

Перспективою подальших досліджень виступає розроблення моделі розвитку професійної компетентності майбутніх фахівців з фізичної культури $і$ спорту Збройних Сил України з урахуванням відповідних педагогічних умов.

\section{ЛІТЕРАТУРА}

1. Смолюк А.І. Професійний саморозвиток майбутніх учителів початкової школи в освітньому середовищі педагогічного коледжу: дис. ... канд. пед. наук зі спеціальності 13.00.04: Теорія i методика професійної освіти. Східноєвропейський національний університет імені Лесі Українки; Національний педагогічний університет імені М.П. Драгоманова, Київ, 2017. 240 с.

2. Гершунский Б.С. Философия образования : учебн. пособ. для студентов высших и средних педагогических учебных заведений. М.: Московский психолого-социальный институт, 1998. $432 \mathrm{c}$.

3. Фіцула М.М. Педагогіка: навч. посіб. для студ. вищих пед. закладів освіти. К.: Академія, 2002. $528 \mathrm{c.}$

4. Погребняк Д.В. Організаційно-педагогічні умови розвитку фахової компетентності начальників фізичної підготовки і спорту військових частин Збройних Сил України в системі післядипломної освіти. Вісник Житомирського державного університету імені Івана Франка. Педагогічні науки. 2018. Випуск 4 (95). С. 160-165.

5. Литвин А.В. Методологічні засади поняття «педагогічні умови»: на допомогу здобувачам наукового ступеня. Львів: СПОЛОМ, 2014. 76 с.

6. Вдовичин Т.Я. Обгрунтування організаційно-педагогічних умов для забезпечення навчального процесу майбутніх бакалаврів інформатики. Сучасні інформаційні технології та інноваційні методики навчання в підготовці фахівців: методологія, теорія, досвід, проблеми: 
[зб. наук. пр.]; Редкол.: І.А. Зязюн (голова) та ін. Київ-Вінниця: ТОВ фірма «Планер», 2013. Вип. 34. С. 225-229.

7. Березовська I.В. Особливості розвитку вольових якостей студентів у навчальнопрофесійній діяльності: автореф. дис. ... канд. психол. наук: 19.00.07 «Педагогічна та вікова психологія». Південноукр. держ. пед. ун-т ім. К.Д. Ушинського. Одеса, 2007. 23 с.

8. Зязюн I. Педагогічна спрямованість - найголовніша характеристика майстерності А.С. Макаренка. Імідж сучасного педагога. 2008. № 1-2 (80-81). С. 5-7.

9. Онаць О.В. Практика формування професійної компетентності молодого вчителя. Шлях освіти. 2012. №3. С. 34-39.

10. Діденко О. Умови формування індивідуального стилю педагогічної діяльності викладача військового вищого навчального закладу // Наукові записки Тернопільського державного педагогічного університету. Серія: Педагогіка. 2008. №2. С. 31-34.

11. Шемчук В. Модель формування професійних компетентностей майбутніх офіцерів - фахівців фізичної підготовки і спорту / В. Шемчук, В. Поливанюк, Ю. Муштатов, О. Федоренко, А. Одеров. - Дрогобич : Актуальні питання гуманітарних наук ДДПУ ім. І.Франка, 2020. Вип. 29. Т. 4. - С. 240-248.

12. Шемчук В. А. Педагогічна модель удосконалення спеціальної фізичної підготовленості майбутніх офіцерів засобами службово-прикладних єдиноборств /В. А. Шемчук, Н. Б Вербин, О. С. Нестеров, М. М. Василенко, С. В. Малахов. - Запоріжжя : Педагогіка формування творчої особистості у вищій і загальноосвітній школах, 2020. Вип. 71. T. 2. - C. 241-248.

13. Шемчук В. А. Педагогічні умови розвитку управлінського мислення майбутніх магістрів військового управління в системі післядипломної освіти: дис. ... канд. пед. наук: 13.00.04 «Теорія та методика професійної освіти» (Педагогічні науки) / В. А. Шемчук. К., 2012. $-288 \mathrm{c}$.

14. Шемчук В. А. Організаційно-педагогічні умови розвитку управлінського мислення майбутніх магістрів військового управління / В.А. Шемчук // Матеріали III Всеармійської наук.-практ. конф.«Актуальні проблеми становлення особистості професіонала в ризиконебезпечних професіях» - К.: НУОУ, 2011, С. 386-387.

\section{REFERENCES}

1. Smolyuk A.I. Profesiynyy samorozvytok maybutnikh uchyteliv pochatkovoyi shkoly v osvitn'omu seredovyshchi pedahohichnoho koledzhu: dys. ... kand. ped. nauk zi spetsial'nosti 13.00.04: Teoriya i metodyka profesiynoyi osvity. Skhidnoyevropeys'kyy natsional'nyy universytet imeni Lesi Ukrayinky; Natsional'nyy pedahohichnyy universytet imeni M.P. Drahomanova, Kyyiv, 2017. $240 \mathrm{~s}$.

2. Hershunskyy B.S. Fylosofyya obrazovanyya : uchebn. posob. dlya studentov vysshykh y srednykh pedahohycheskykh uchebnykh zavedenyy. M.: Moskovskyy psykholoho-sotsyal'nyy ynstytut, 1998. $432 \mathrm{~s}$.

3. Fitsula M.M. Pedahohika: navch. posib. dlya stud. vyshchykh ped. zakladiv osvity. K.: Akademiya, 2002. $528 \mathrm{~s}$.

4. Pohrebnyak D.V. Orhanizatsiyno-pedahohichni umovy rozvytku fakhovoyi kompetentnosti nachal'nykiv fizychnoyi pidhotovky i sportu viys'kovykh chastyn Zbroynykh Syl Ukrayiny $\mathrm{v}$ systemi pislyadyplomnoyi osvity. Visnyk Zhytomyrs'koho derzhavnoho universytetu imeni Ivana Franka. Pedahohichni nauky. 2018. Vypusk 4 (95). S. 160-165.

5. Lytvyn A.V. Metodolohichni zasady ponyattya «pedahohichni umovy»: na dopomohu zdobuvacham naukovoho stupenya. L'viv: SPOLOM, 2014. $76 \mathrm{~s}$.

6. Vdovychyn T.YA. Obgruntuvannya orhanizatsiyno-pedahohichnykh umov dlya zabezpechennya navchal'noho protsesu maybutnikh bakalavriv informatyky. Suchasni informatsiyni tekhnolohiyi ta innovatsiyni metodyky navchannya $\mathrm{v}$ pidhotovtsi fakhivtsiv: metodolohiya, teoriya, dosvid, problemy: [zb. nauk. pr.]; Redkol.: I.A. Zyazyun (holova) ta in. Kyyiv-Vinnytsya: TOV firma «Planer», 2013. Vyp. 34. S. 225-229. 
7. Berezovs'ka I.V. Osoblyvosti rozvytku vol'ovykh yakostey studentiv u navchal'noprofesiyniy diyal'nosti: avtoref. dys. kand. psykhol. nauk: 19.00.07 «Pedahohichna ta vikova psykholohiya». Pivdennoukr. derzh. ped. un-t im. K.D. Ushyns'koho. Odesa, 2007. 23 s.

8. Zyazyun I. Pedahohichna spryamovanist' - nayholovnisha kharakterystyka maysternosti A.S. Makarenka. Imidzh suchasnoho pedahoha. 2008. № 1-2 (80-81). S. 5-7.

9. Onats' O.V. Praktyka formuvannya profesiynoyi kompetentnosti molodoho vchytelya. Shlyakh osvity. 2012. №3. S. 34-39.

10. Didenko O. Umovy formuvannya indyvidual'noho stylyu pedahohichnoyi diyal'nosti vykladacha viys'kovoho vyshchoho navchal'noho zakladu // Naukovi zapysky Ternopil's'koho derzhavnoho pedahohichnoho universytetu. Seriya: Pedahohika. 2008. №2. C. 31-34.

11. Shemchuk, V. Model formuvannia profesiinykh kompetentnostei maibutnikh ofitserivfakhivtsiv fizychnoi pidhotovky i sportu /V. Shemchuk, V. Polyvaniuk, Yu. Mushtatov O. Fedorenko, A. Oderov. - Drohobych : Aktualni pytannia humanitarnykh nauk DDPU im. I. Franka, 2020. № 29. T. 4. - S. 240-248.

12. Shemchuk, V. A., N. B Verbyn, O. S. Nesterov, M. M. Vasylenko, Ye. V. Malakhov. (2020). Pedahohichna model udoskonalennia spetsialnoi fizychnoi pidhotovlenosti maibutnikh ofitseriv zasobamy sluzhbovo-prykladnykh yedynoborstv [Pedagogical model of improvement of special physical training of future officers by means of service-applied martial arts]. Pedahohika formuvannia tvorchoi osobystosti u vyshchii i zahalnoosvitnii shkolakh, Vyp. 71. T. 2., 241-248.

13. Shemchuk, V. A. (2012). Pedahohichni umovy rozvytku upravlinskoho myslennia maibutnikh mahistriv viiskovoho upravlinnia v systemi pisliadyplomnoi osvity. Avtoref. dys. ... kand. ped. nauk: spec. 13.00.04 «Teoriia ta metodyka profesiinoi osvity». [Pedagogical conditions for the development of managerial thinking of future masters of military management in the system of postgraduate education. PhD ped. sci. diss.]. Kyiv. 288 p.

14. Shemchuk, V. A. Orhanizatsiyno-pedahohichni umovy rozvytku upravlinskoho myslennia maibutnikh mahistriv viiskovoho upravlinnia / V. A. Shemchuk // Materials III Vsearmiiskoi nauk.prakt. konf. «Aktualni problemy stanovlennia osobystosti profesionala v ryzykonebezpechnykh profesiiakh»-K.: NUOU, 2011, S. 386-387.

\section{Резюме}

Александр Петрачков, кандидат педагогических наук, доцент Национальный университет обороны Украины имени Ивана Черняховского

Виталий Поливанюк,

Национальный университет обороны Украины имени Ивана Черняховского

\section{ОПРЕДЕЛЕНИИ ПЕДАГОГИЧЕСКИХ УСЛОВИЙ ФОРМИРОВАНИЯ ПРОФЕССИОНАЛЬНОЙ КОМПЕТЕНТНОСТИ БУДУЩИХ СПЕЦИАЛИСТОВ ПО ФИЗИЧЕСКОЙ КУЛЬТУРЕ И СПОРТУ ВООРУЖЕННЫХ СИЛ УКРАИНЫ}

Проанализированы теоретические подходы к определению категории «педагогические условия». Исследованы современные точки зрения по определению организационнопедагогических условий формирования профессиональной компетентности будущих военных специалистов по физической культуре и спорту Вооруженных Сил Украины.

Приведень важно для этого исследования трактовки термина «условие» с психологической точки зрения как совокупности явлений внешней и внутренней среды, которые могут оказывать влияние на развитие конкретного явления, опосредуется активностью лица или определенной группь лиц. Рассмотрен в качестве значимых условий 
профессионального становления личности мотивы, направленность личности, ее склонности, интересы, общие и особые способности, обстоятельства воспитания $u$ обучения, организачии профессионального и образовательной среды, доступ к культурным изенностям, состояние социального окружения и тому подобное.

Освещзены позиции ученых и исследователей о том, что формирование профессиональной компетентности является диалектическим прочессом, который обусловлен внешними и внутренними стимулами, позволяет выделить организационнопедагогические условия стимулирования профессиональной компетентности будущего военного специалиста. Определены внешние и внутренние аспекты формирования профессиональной компетентности. Во внешнем аспекте формирования профессиональной компетентности стимулируется иеленаправленным включением курсантов в разнообразные виды деятельности. Именно от того, насколько тесным и плодотворным является взаимодействие среды высшего военного учебного заведения и личностных возможностей курсанта, настолько успешным оказывается формирования профессиональной компетентности будущих военных специилистов. Во внутреннем аспекте формирования профессиональной компетентности раскрывается через профессиональное осознание личности себя как будущего профессионала, осознанной способности к проектированию собственного профессионального пути, критическом отношении к своим профессиональным достижениям. Будущий специалист внутренне стремится $\kappa$ профессиональному саморазвитию, то есть на уровне личности наблюдаются определенные качественные изменения в стремлении $\kappa$ профессиональному самосовершенствованию, выработке определенного стиля профессиональной деятельности.

Ключевые слова: организаиионно-педагогические условия, профессиональная компетентность, профессиональное развитие, саморазвитие, педагогическое моделирование.

\title{
SUMMARY
}

\author{
Oleksandr Petrachkov, \\ candidate of pedagogical sciences, Associate Professor \\ The National Defence University of Ukraine \\ named after Ivan Cherniakhovskyi \\ Vitaliy Polyvanyuk, \\ The National Defence University of Ukraine \\ named after Ivan Cherniakhovskyi
}

\section{DETERMINATION OF PEDAGOGICAL CONDITIONS OF FORMATION OF PROFESSIONAL COMPETENCE OF FUTURE SPECIALISTS IN PHYSICAL CULTURE AND SPORTS OF THE ARMED FORCES OF UKRAINE}

Theoretical approaches to the definition of the category "pedagogical conditions" are analyzed. Modern points of view on determining the organizational and pedagogical conditions for the formation of professional competence of future military specialists in physical culture and sports of the Armed Forces of Ukraine are studied.

The interpretation of the term "condition" from the psychological point of view as a set of phenomena of external and internal environment which can influence development of the concrete phenomenon mediated by activity of the person or a certain group of persons is resulted important for this research. Motives, orientation of a person, his inclinations, interests, general and special abilities, circumstances of upbringing and training, organization of professional and educational environment, access to cultural values, state of social environment, etc. are considered as significant conditions of professional formation of personality.

The positions of scientists and researchers that the formation of professional competence is a dialectical process, which is due to external and internal incentives, which allows to distinguish 
organizational and pedagogical conditions for stimulating professional competence of the future military specialist. External and internal aspects of professional competence formation are determined. In the external aspect, the formation of professional competence is stimulated by the purposeful inclusion of cadets in various activities. It is from the close and fruitful interaction of the environment of a higher military educational institution and the personal capabilities of the cadet that the formation of professional competence of future military specialists is so successful. In the internal aspect, the formation of professional competence is revealed through the professional awareness of the individual as a future professional, the conscious ability to design their own career path, a critical attitude to their professional achievements. The future specialist internally strives for professional self-development, ie at the level of the individual there are certain qualitative changes in the desire for professional self-improvement, the development of a certain style of professional activity.

Keywords: organizational and pedagogical conditions, professional competence, professional development, self-development, pedagogical modeling. 